\title{
CHEMICAL DEPOL YMERIZATION OF WASTE PLASTICS IN BUBBLE COLIUMN REACTOR FOR BLENDED FABRICATION
}

\author{
Mohammed Alzuhairi ${ }^{1}$ \\ mohammed.a.alzuhairi@uotechnology.edu.iq
}

\author{
Mohanad N. Alsroofy ${ }^{1}$ \\ 10769@uotechnology.edu.iq
}

Aynoor A. Jan ${ }^{1}$

aynoor.alijan@gmail.com

\author{
Waleed Bdaiwi ${ }^{2}$ \\ wdbedeawy@yahoo.com \\ ${ }^{1}$ University of Technology -Department of Materials Engineering - Iraq \\ ${ }^{2}$ Anbar University- College of Education for Pure Sciences - Iraq
}

\begin{abstract}
The degradation of waste plastics in the environment is such an essential issue for Earth protection. This study indicated the importance of using waste bottles to produce recycled depolymerization Polyethylene Terephthalate (DPET). The bubble column reactor technique and its effect in the depolymerization process have been investigated. The DPET with Polymethyl methacrylate (PMMA) has been used to fabricate the hybrid polymer to improve the mechanical properties. Thus, different percentages (1, 2, 3, 5, and $10 \%)$ of (DPET) are used to surmise its repercussions on the mechanical properties of the polymer. These ramifications were studied through a sequence of research laboratory tests, including tensile strength, Charpy impact, and shore-D hardness, and Fourier Transform Infrared Spectroscopy (FTIR) analysis. The results show a development interest, especially for impact strength and surface hardness, where both tests show compatible results, especially at (10\%) of DPET. At the same time, maximum results of tensile strength are at (3\%). FTIR analysis shows a chemical reaction between DPET and PMMA, which significantly improves the characteristics and makes it a wide range of available applications.
\end{abstract}

Keywords: depolymerization, PET, PMMA, Shore-D, Impact strength.

\section{التفكيك الكيمياوي للنفايات البلاستيكية في مفاعل عمود الفقاعة لتصنيع الخلائط

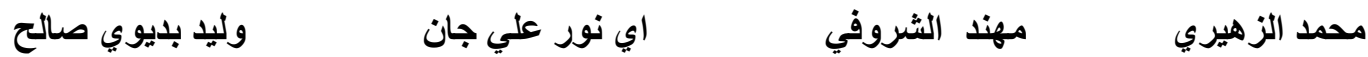

الخلاصة

يعد التدهور الحاصل في تر اكم النفايات البلاستيكية في البيئة أصبح معالجتها قضية أساسية لحماية الأرض. أثنارت هذه ألنا

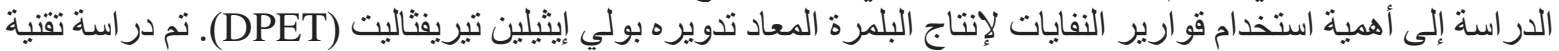

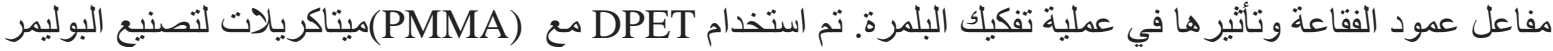

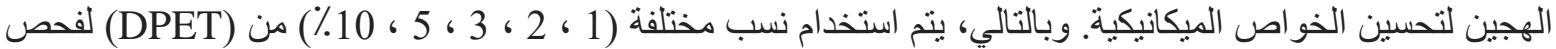
تأثثر ها على الخو اص الميكانيكية للبوليمر. تمت در اسة من خلال سلسلة من الاختبار ات المعملية البحثية، بما في ذللك قوة

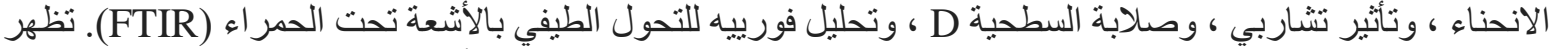

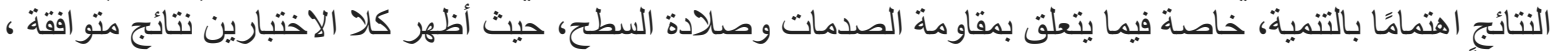

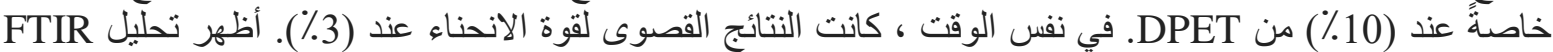

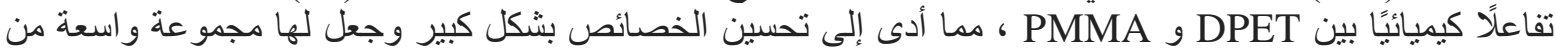
التطبيقات المتاحة. 


\section{INTRODUCTION}

The global rapid industrial enterprise pollution community growth has exponentially incremented the production and ingestion of plastics Chirag B,(2018). Incessant innovation explains that contemporary plastic production has been elevated by approximately ( 311 million tons) on a worldwide basis ) Owusu,(2018). This development production and utilization of plastic have produced significant collective and environmental altercation in the jettisoning of their wastes. Some countryside has preferable solutions of waste administration for plastic while in other nations the plastic wastes terminus up with landfilling Owusu,(2018). The landfill process of plastic is of no monetary value; in this way, the waste can't be exploited. In the contemporary world, rational and more effective replacements are essential to efficiently administering plastic waste from the environment; recycling may be the best option Owusu,(2018). There are contrastive types of plastics; various plastics are not recyclable because of their composition and chemical properties. This plastic pyrolysis procedure (energy recovery) can be another option instead of recycling Anuar Sh.,(2017). The other kind of plastic can be transmuted into its indigenous monomeric situation by chemical or thermal processes Acosta,(2015) and Kikuchi,(2014). (PMMA) resin is the most widely utilized material for producing the dental plate since it combines good characteristics, such as lightweight and economical fabrication and unavailability of toxicity Carlsson G. E,(2010) and T. R. Meng,(2005). It's considered a kind of thermoplastic utilized globally in diverse applications, e.g., surface coating, electrically insulating material, and glassy all-weather layers. PMMA believes the fundamentals of a lot of materials tribe consisting of Plexiglas ${ }^{\circledR}$ and Lucite ${ }^{\circledR}$ Pereira, (2018). The multiple-use and cost production of it and preserve the environment from landfilling of PMMA. Although, PMMA has various disadvantages that demand to be addressed due to its unsatisfactory mechanical properties, such as fatigue defeat and impact resistance T. R. Meng,(2005) and Pratibha Y.,(2012). For instance, structure amendment to the composition, such as fillers, might improve PMMA mechanical properties Pratibha Y.,(2012) and T. K. Mowade,(2012). Previous studies appeared that glass fibers, much better than other types of fibers e.g., aramid carbon fibers, polyethylene, and nylon), could reveal poor adhesion with resin matrix Alla R. K.,(2013)- Uzun G.,(1999). It's appeared that the mechanical properties of PMMA composite be decided by bonding between the matrix and glass fiber reinforcement L. M. Goguta,(2006). To achieve an elevated level of adhesion between matrix and support materials, surface treatment of glass fiber with coupling agent previously mixing with resin matrix L. M. Goguta,(2006) and P. K. Vallittu,(1997). Numerous studies mentioned enhancement in mechanical properties of PMMA/silane such as flexural and impact strength, as fiber (G.F.s) P. K. Vallittu,1997- Prasad A. H.,(2011). Polyethylene terephthalate (PET) is thermoplastic polyester (semi-crystalline material), its characterized by a high level of strength, transparentness, and safety R. Lo' pez-Fonseca,(2011). High molecular weight can be manufactured by subsequent polymerization level accomplishment in a solid-state at a low-grade temperature V. Sinha,(2010). This effective process to carry away all volatile impurities, such as water, free glycol, and acetaldehyde V. Sinha,(2010). The high molecular weight of PET. is necessary for enhanced mechanical properties like creep resistance, stiffness, and toughness while giving adequate flexibility to withstand bursting and fracture under pressure V. Sinha,(2010). The present work focused on the study of the effect of DPET and PMMA on the mechanical properties such as: Tensile strength, Charpy impact test, and Shore-D hardness. Also, study the extent of a chemical reaction between two materials using Fourier Transform Infrared Spectroscopy (FTIR) analysis. 


\section{DEPOLYMERIZATION OF POLYETHYLENE TEREPHTHALATE (PET)}

PET is a globally utilized material-grade thermoplastic with a high level of impact and chemical resistance at ambient temperature Kamber,(2010). It's frequently used in injectionmolded patron packaging merchandise like soft drink bottles and water Kamber,(2010). Even though PET does not cause chemical hazards to the environment, the increased usage of plastic cast away like, water bottles into landfills occasion a main environmental pollution dilemma Kamber,(2010), and Alzuhairi M,(2018). Moreover, recycling of PET assistances as a raw material in petrochemical commodities and energy. The quality of depolymerized PET can be guaranteed using chemical recycling; this process includes segmentation of the practical ester groups using reagents like, glycolysis, methanolysis, and hydrolysis Farahat,(2001) and Hussein A.,(2018). All of these can be produced at a high level of temperature with the presence of manganese acetate (catalysts) Chen,(2001), ethanoic acid, "lithium hydroxide, sodium/potassium sulfate Shukla,(2005), and titanium (IV) n-butoxide Pardal, F.,(2006)". Chemical recycling of polyethylene terephthalate is not oceanic practiced because of un convenient economics comparative to mechanical recycling and economical be of starting monomer Kamber,(2010). Consequently, the chemical recycling of PET is wide-scale implementation due to its positive effect on the environment and economically feasibleness Kamber,(2010).

\section{EXPERIMENTAL}

\section{Materials and Method}

Cold Poly-methyl-methacrylate (PMMA) (bulk density $\sim 1.20 \mathrm{~g} / \mathrm{cm}^{3}$ ) works as matrix phase, and pure depolymerization polyethylene terephthalate (DPET) was prepared by bubble column reactor. Where, PET bottles cut into small pieces $(3 \mathrm{~mm})$, washed, dried, and mixed with Ethylene glycol put in bubble column reactor (molar ratio $=4: 1$ ) In addition to, nano $\mathrm{MgO}\left(0.5 \%\right.$ wt of PET) at $\left(190-195^{\circ} \mathrm{C}\right)$,were used as catalyst, with nitrogen gas flowing from below to achieve bubbles, that play a major role in increasing mass and heat transfer. Thus; reducing reaction time (40 min). Full depolymerization will produce monomer, dimer, and trimer, and agglomerated. By distillation process, separates the liquid part from the solid. When the remaining part hardens, it is ground and then washed with distilled water for $(0.5 \mathrm{hr})$. Then it is filtered and dried. DPET used to produce polymer composite, as shown in Figure (1). PMMA was mixed with (1, 2, 3, 5, and 10) wt. \% of DPET. Wax mold was used to produce (30) specimens were produced (twenty samples per mechanical test). FTIR analyses of the best percentage of the mechanical properties polymer can products were performed on $\mathrm{KBr}$ pellets.

Tensile Strength Test: The tensile properties were measured according to (ASTM D- 638) at a crosshead speed of $5 \mathrm{~mm} / \mathrm{min}$ using INSTRON(M 3382, UK) universal testing machine.

Impact Strength Test: Samples for this mechanical test were made according to BS2000ISO-1567 with sample dimensions $(55 \times 10 \times 10) \mathrm{mm}$, with V-notch shape $(2.5 \mathrm{~mm}$ deep $\times$ $10 \mathrm{~mm}$ width). Digital Charpy impact test machine was utilized at laboratory temperature, sample was fixed in horizontal position utilizing two beams $(40 \mathrm{~mm})$. A dip weight $(0.5 \mathrm{~J})$ was launched at the middle on the reverse side of the notch M. Gad,(2016) and N. S. Ihab,(2011). 
Shore- D Hardness: is an instrument used to measure the surface hardness of rigid elastomers (thermoplastics and thermosets) utilizing an indenter force by graduate spring Koch T. The hardness measurement is calculated by permeation depth of the indenter under the influence (ASTM D2240) Koch T. The loading force of shore hardness D: $(0 \mathrm{~N} \leq \mathrm{F} \leq$ $44.5 \mathrm{~N})$ with spherical cap $(0 \mathrm{~mm} \leq \mathrm{h} \leq 2.5 \mathrm{~mm})$, with range value $(0-100)$ Koch $\mathrm{T}$. The mechanical properties of pure PMMA and PET, shown in Table (1).

Fourier Transform Infrared Spectroscopy (FTIR): is one of the analytical techniques that depend upon atoms of molecule vibration; an infrared spectrum results from passing infrared radiation over a sample. Some samples absorb the infrared radiation while other types of it are transmitted Jan A.(2017). Department of Materials Engineering/ University of Technology conducted FTIR used in this study.

\section{RESULTS AND DISCUSSION}

Average values, and statistically significant differences of flexural strength, impact strength, and shore D-hardness are shown in Table(2). The addition of different concentrations of DPET conspicuously enhances the flexural strength with increasing in DPET content. Increasing in DPET content especially, at (3\%) wt improved the tensile strength of polymer composite. While as seen in figure (2), the impact strength showed contrastive results of tensile strength. Where, the improvement of impact strength increases gradually with DPET content, especially at (10\%) wt, it has improved nearly twice as compared to (0\%) wt content of DPET. Shore D-hardness appeared a corresponding results was obtained from impact strength, figure (2). FTIR analysis contains absorption of infrared photons, where the difference in bond vibrational depends on the state of the molecular Jan A.,(2017). Figure (3) illustrates FTIR of DPET, the finger-print distinctive vibration band of $\mathrm{C}=\mathrm{O}$ in the range (1000-1727) $\mathrm{cm}^{-1}$. While the stretching band, $\mathrm{C}-\mathrm{H}$ refers to $\mathrm{CH}_{3}$ group (methyl group) in the rang (3000-2900) $\mathrm{cm}^{-1}$. The symmetric and asymmetric $\mathrm{C}-\mathrm{H}$ stretching modes appear at (1300-1450) $\mathrm{cm}^{-1}$. In-addition to, C-C bands appeared at (800-1000) $\mathrm{cm}^{-1}$ Ahmad S.,(2007). Besides, the PMMA spectrum Figure(4), appeared two slight bands at functional groups: C-H (2949.81-2993.80 $\left.\mathrm{cm}^{-1}\right)$, and signal band of $\mathrm{C}=\mathrm{O}$ at $\left(1724.14 \mathrm{~cm}^{-1}\right)$. band at $\left(2882-2951 \mathrm{~cm}^{-1}\right)$, double band of $\mathrm{C}=\mathrm{O}$ ester carbonyl group at $\left(1718 \mathrm{~cm}^{-1}\right.$, and at wave length $\left(1111 \mathrm{~cm}^{-1}\right)$ asymmetrical stretching band of (C-O-C)was appeared. Also, at (727-881 $\mathrm{cm}^{-1}$ indicating to C-Haromatic ring. Figure (6), shows FTIR spectroscopy for the best mechanical properties of a polymer composite that appeared at (10 wt\%) of DPET content. The result presents broadband at wavelength (3000-3500) $\mathrm{cm}^{-1}$ of overlapping stretching of depolymerization. Therefore, the chemical reaction has existed during the curing process; this enhances the impact strength and shore-D hardness due to composite compositional morphology.

\section{CONCULUSIONS}

1. The bubble column technique provides the depolymerization process an excellent heat and mass transfer for effective reaction time.

2. Tensile strength, impact strength, and surface hardness have improved by the additives of the depolymerization polyethylene terephthalate (DPET).

3. FTIR spectroscopy appeared to be a chemical reaction between PMMA and DPET, reflecting on the improvement in blended morphology. This new mixture could be beneficial in adhesive, cosmetic materials and may be used as a front paint for cars. 


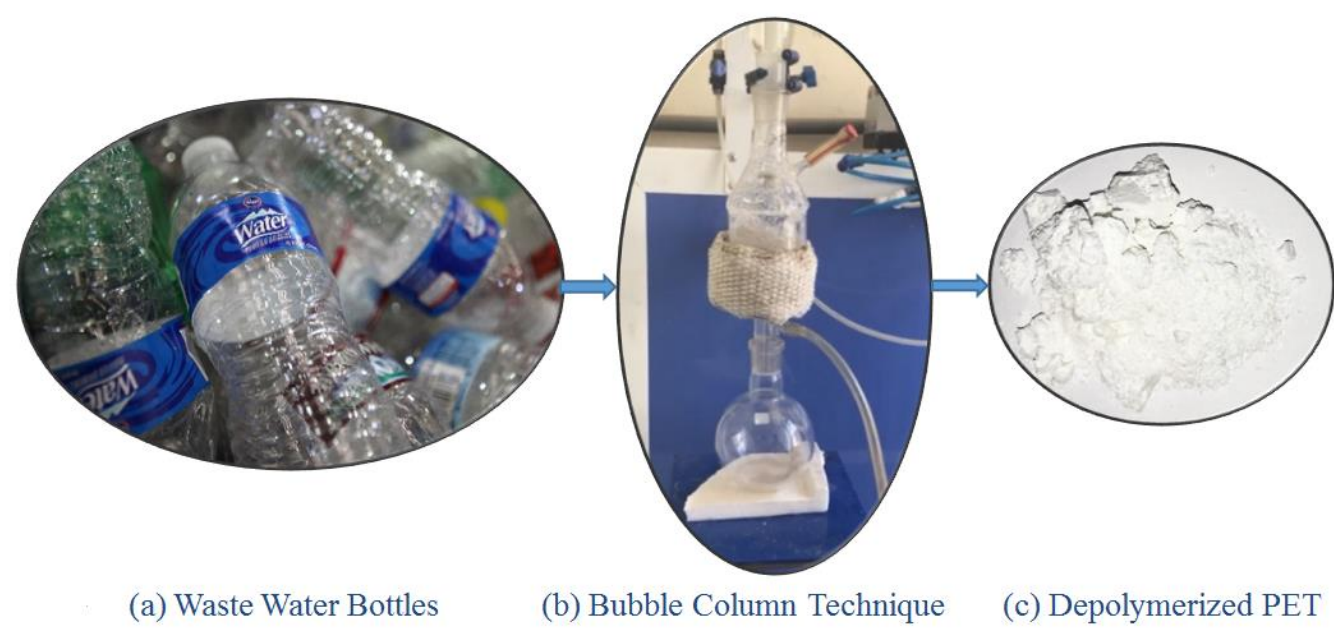

Fig. (1) Production of DPET from waste bottles (Hussein A.(2018)).

Table (1) Mechanical Properties of PMMA and PET.

\begin{tabular}{|c|c|c|c|}
\hline $\begin{array}{c}\text { Mat.s/Mechanical } \\
\text { Properties }\end{array}$ & $\begin{array}{c}\text { Tensile } \\
\text { Strength(MPa) }\end{array}$ & $\begin{array}{c}\text { Impact Strength } \\
(\mathbf{J} / \mathbf{m})\end{array}$ & $\begin{array}{c}\text { Shore- D } \\
\text { Hardness }\end{array}$ \\
\hline PMMA & 59 & 55 & 59 \\
\hline PET & 61.7 & $4600(4.6 \mathrm{KJ} / \mathrm{m})$ & 82 \\
\hline
\end{tabular}

Table(2) Results of mechanical tests.

\begin{tabular}{|l|c|c|c|c|}
\hline No. & DPET \% & Tensile Strength(MPa) & Impact Strength $\left(\mathbf{J} / \mathbf{~ c m}^{2}\right)$ & Shore -D Hardness \\
\hline 1. & 0 & 3.9 & 0.28 & 77.6 \\
\hline 2. & 1 & 4.15 & 0.30 & 80.4 \\
\hline 3. & 2 & 4.7 & 0.35 & 81.8 \\
\hline 4. & 3 & 5.6 & 0.40 & 83.4 \\
\hline 5. & 5 & 5.3 & 0.5 & 84.6 \\
\hline 6. & 10 & 5.3 & 0.65 & 87.2 \\
\hline
\end{tabular}




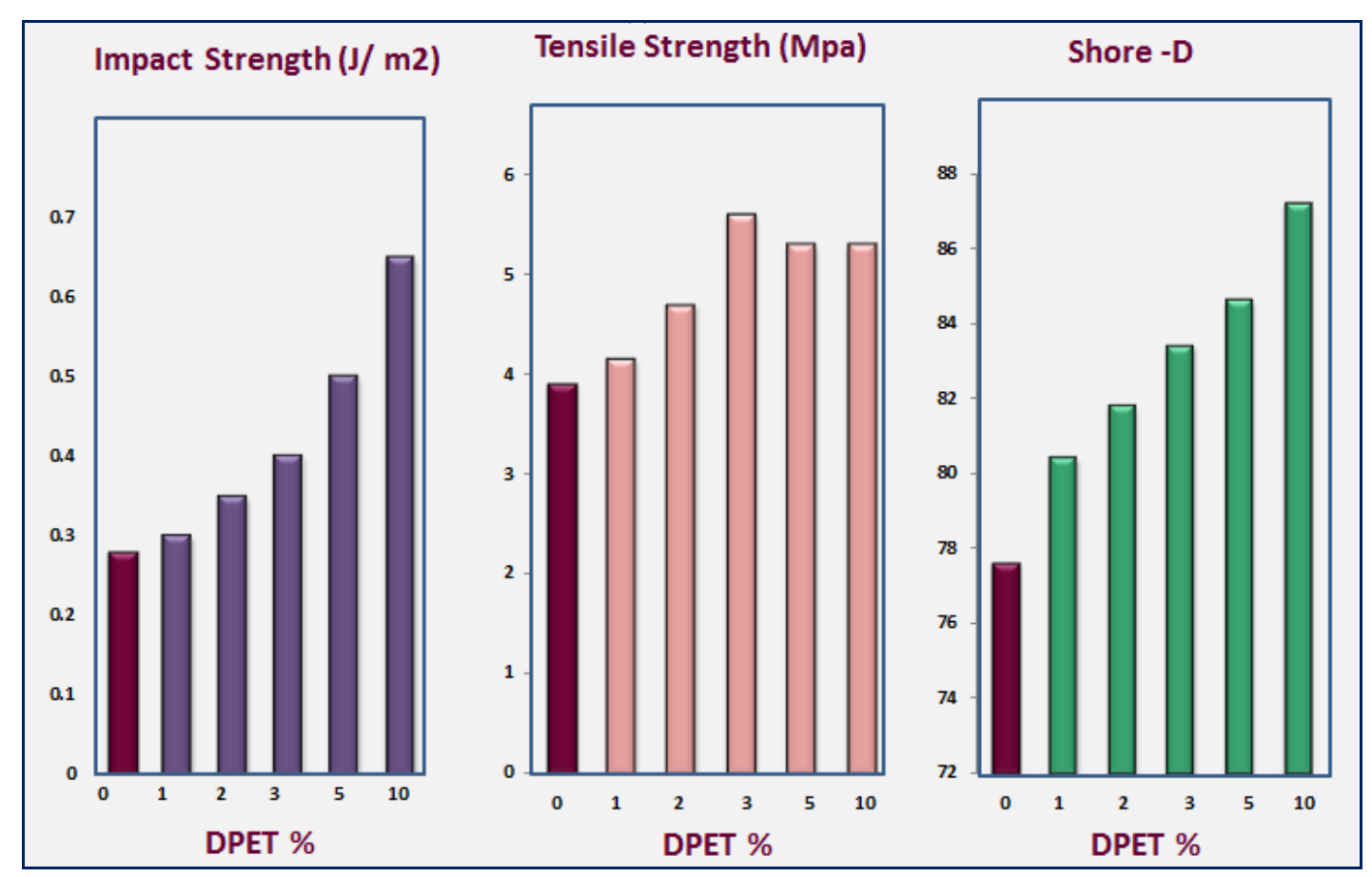

Fig. (2) Column chart of mechanical properties results.

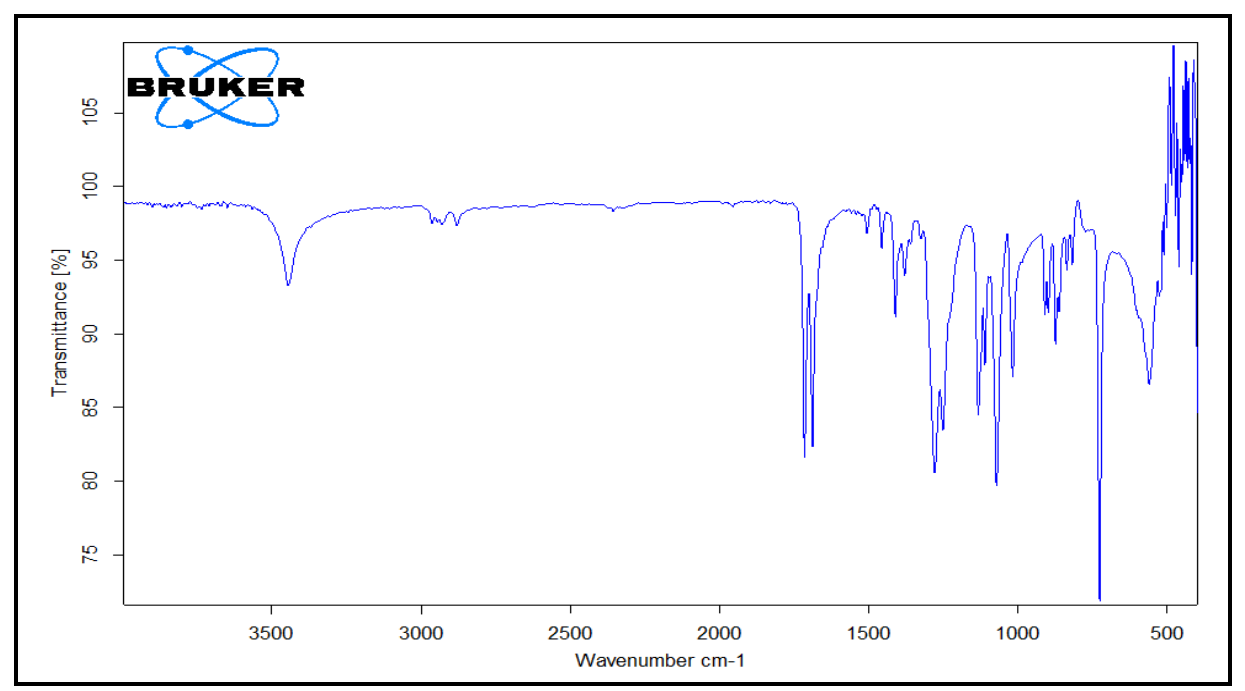

Fig. (3): FTIR test of DPET. 


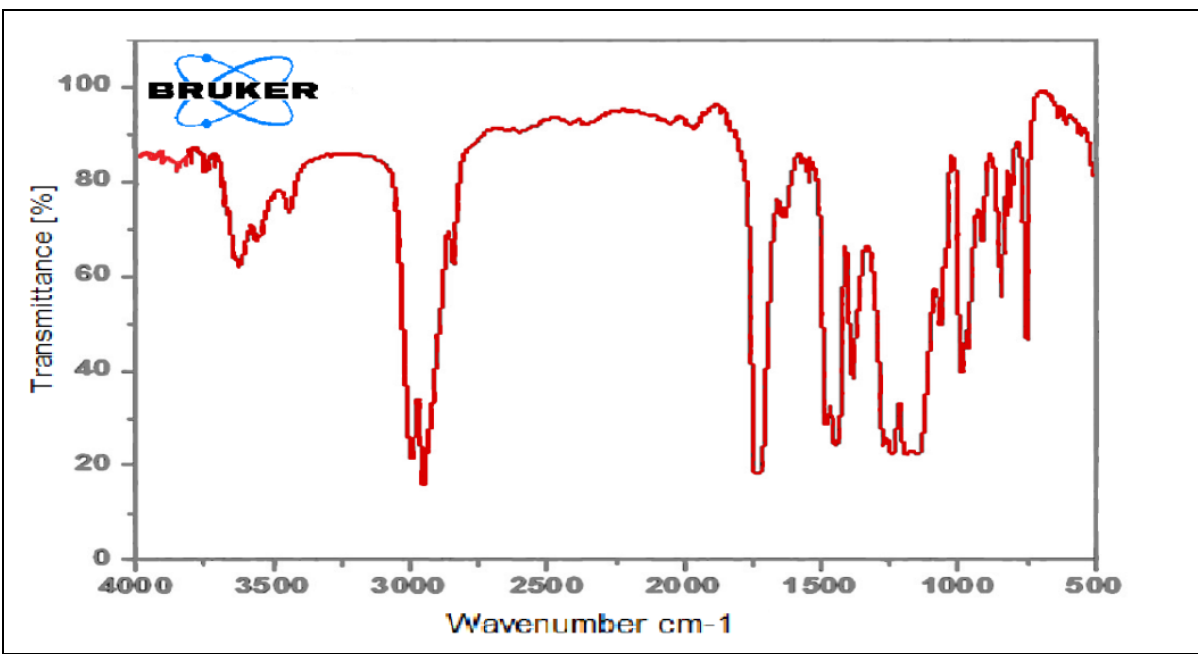

Fig. (4) FTIR test of PMMA

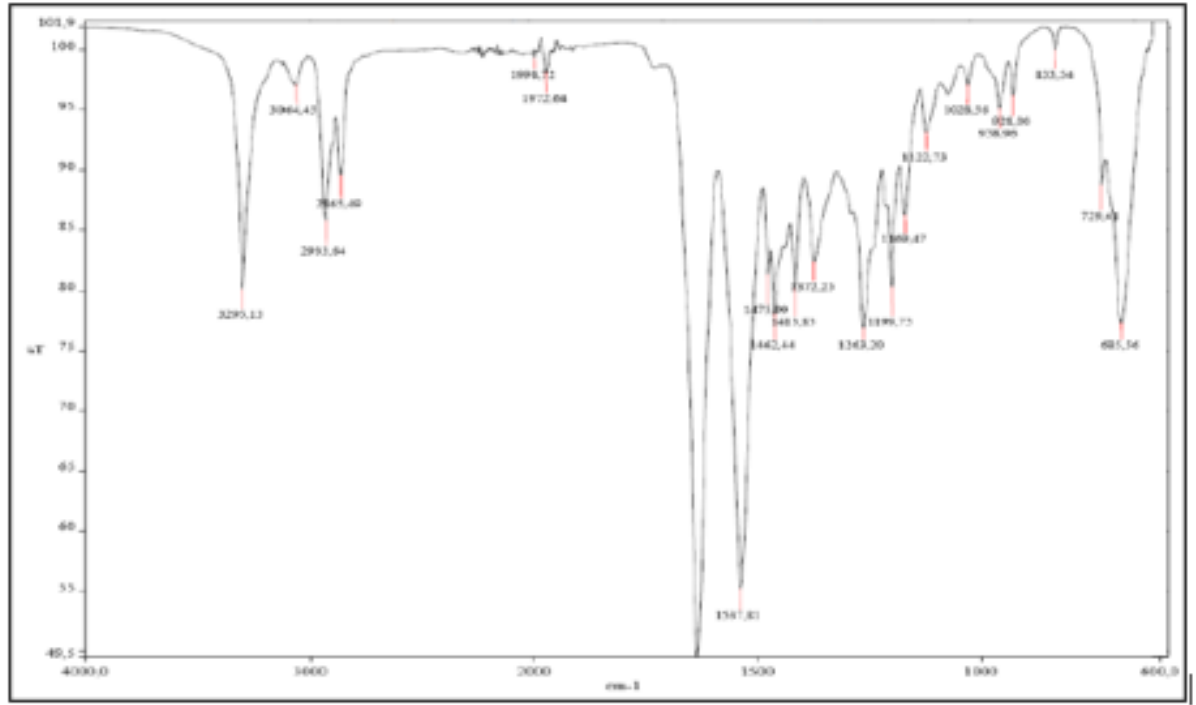

Fig. (5) FTIR test of Pure PET.

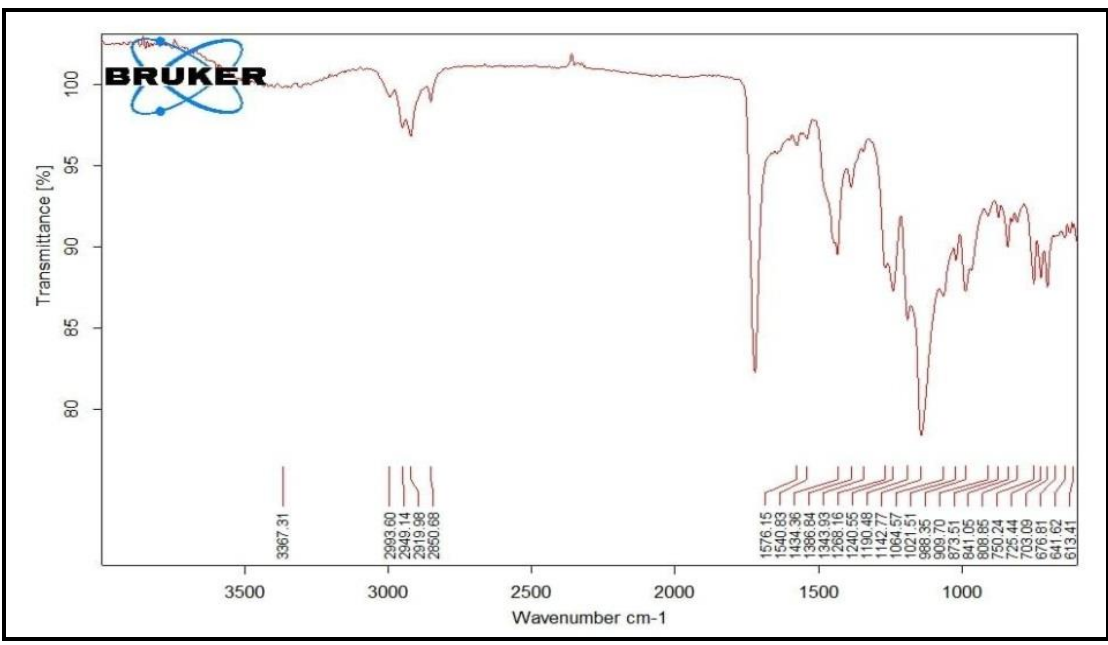

Fig. (6) FTIR of (10)\% of polymer composite. 


\section{REFERENCES}

Ahmad S.,Ahmad Sh., and Agnihotry S. A.A," Synthesis and characterization of in situ prepared poly(methyl methacrylate) nanocomposites", Indian Academy of Sciences, Bull. Mater. Sci., Vol. 30, No. 1, Feb., pp. 31-35, 2007.

Anuar Sh., S.D., Abnisa, F., Wan D., W.M.A., Aroua, M.K.,. "Energy recovery from pyrolysis of plastic waste: study on non-recycled plastics (N.R.P.) data as the real measure of plastic waste". Energy Convers. Manag. 148, 925-934. 2017

Acosta, R.I., Gross, K.C., Perram, G.P., "Thermal degradation of Poly(methyl methacrylate) with a $1.064 \mu \mathrm{m} \mathrm{Nd:YAG} \mathrm{laser} \mathrm{in} \mathrm{a} \mathrm{buoyant} \mathrm{flow".} \mathrm{Polymer} \mathrm{degradation} \mathrm{and} \mathrm{stability} \mathrm{.} \mathrm{121,}$ 78-89, 2015.

Alla R. K., S. Sajjan, V. R., Ginjupalli K., Upadhya N., "Influence of fiber reinforcement on the properties of denture base resins," Journal of Biomaterials and Nanobiotechnology, vol. 4, no. 1, pp. 91-97, 2013.

Alzuhairi M.," Bubble Column and C.F.D. Simulation for Chemical Recycling of Polyethylene Terephthalate", A.I.P. Conference Proceedings, American Institute of Physics, 030041 (2018)

British Standard Institution 2000-ISO 1567, Dentistry-Denture Base Polymer, International Organization for Standardization, Geneva, Switzerland, 1999.

Chen S.-Y., W.-M. Liang, Yen P.-S., "Reinforcement of acrylic denture base resin by incorporation of various fibers," Journal of Biomedical Materials Research, vol. 58, no. 2, pp. 203-208, 2001.

Chen, C.H.; Chen, C.Y.; Lo, Y.W.; Mao, C.F.; Liao, W.T. Studies of glycolysis of poly (ethylene terephthalate) recycled from postconsumer soft-drink bottles. I. Influences of glycolysis conditions. J. Appl. Polym. Sci., 80, 943-948, 2001.

Carlsson G. E., Omar R., "e future of complete dentures in oral rehabilitation: a critical review," Journal of Oral Rehabilitation, vol. 37, no. 2, pp. 143-156, 2010.

Chirag B. Godiyaa, Serena G., Stefano M., Maria S. P., Nicola S., Enrico M., , Depolymerization of waste poly(methyl methacrylate) scraps and purification of depolymerized products", Journal of Environmental Management, 31 Oct. 2018.

Farahat, M.S.; Nikles, D.E. On the U.V. curability and mechanical properties of novel binder systems derived from poly (ethylene terephthalate) (P.E.T.) waste for solventless magnetic tape manufacturing, 1. acrylated oligoesters. Macromol. Mater. Eng. 286, 2001.

Hussein A.,A., Alzuhairi A., and. Aljanabi N.,H," Degradation and depolymerization of plastic waste by local bacterial isolates and bubble column reactor", A.I.P. Conference Proceedings, American Institute of Physics, 030081 (2018). 
Jan A.," Properties of green concrete using recycled materials", Thesis, Materials Engineering Department, University of Technology, 2017

Kikuchi, Y., Hirao, M., Ookubo, T., Sasaki, A., "Design of recycling system for poly(methyl methacrylate) (PMMA)". Part 1: recycling scenario analysis. Int. J. Life Cycle Assess. 19, 120-129, 2014.

Kamber, N.E.; Tsujii, Y.; Keets, K.; Waymouth, R.M.The depolymerization of poly (ethylene terephthalate) (P.E.T.) using Nheterocyclic carbenes from ionic liquids. J. Chem. Educ, 87, 519-521, 2010.

Koch T., Bierögel C., Seidler S. , " "Instrumented Hardness Values-data." Polymer Solids and Polymer Melts-Mechanical and Thermomechanical Properties of Polymers". Springer, Berlin, Heidelberg, Pp. 450-452, 2014.

L. M. Goguta, D. Bratu, and F. Topala, "Impact strength of acrylic heat curing denture base resin reinforced with E-glass10 International Journal of Dentistry fibers," Temporomandibular Joint Disorders, vol. 56, pp. 88-91, 2006.

M. Gad, A. Rahoma, A. M. Al-,obity, and A. ArRejaie, "Influence of incorporation of ZrO2 nanoparticles on the repair strength of polymethyl methacrylate denture bases", International journal of nanomedicine, 5633, 2016.

M. Gad, A. Rahoma, A. M. Al-,obity, "Effect of polymerization technique and glass fiber addition on the surface roughness and hardness of PMMA denture base material," Dental Materials Journal, vol. 37, no. 5, pp. 746-753, 2018.

N. S. Ihab and M. Moudhaffar, "Evaluation the effect of modified nano-fillers addition on some properties of heat cured acrylic denture base material," Journal of Baghdad College of Dentistry, vol. 23, pp. 23-29, 2011.

Owusu, P.A., Banadda, N., Zziwa, A., Seay, J., Kiggundu, N.," Reverse engineering of plastic waste into useful fuel products", Journal of Analytical and Applied Pyrolysis , 130, 285-293, 2018.

Pratibha Y., Mittal R., Sood V. K., "Effect of incorporation of silane-treated silver and aluminum micro particles on strength and thermal conductivity of PMMA," Journal of Prosthodontics, vol. 21, no. 7, pp. 546-551, 2012.

Pereira, J.P.C., van der W., L.A.M., Straathof, A.J.J.," Perspectives for the microbial production of methyl propionate integrated with product recovery". Bioresour. Technol. 256, 187-194, 2018.

P. K. Vallittu and K. Narva, "Impact strength of a modified continuous glass fiber-poly (methyl methacrylate)," International Journal of Prosthodontics, vol. 10, pp. 142-148, 1997. 
Prasad A. H., Kalavathy A., Mohammed H. S., "Effect of glass fiber and silane treated glass fiber reinforcement on impact strength of maxillary complete denture," Annals and impact strength of maxillary complete denture," Annals and Essences of Dentistry, vol. 3, no. 4, pp. 7-12, 2011.

Pardal, F.; Tersac, G. "Comparative reactivity of glycols in PET glycolysis". Polymer degradation and stability ,91, 2567-2578, 2006.

R. Lo’ pez-Fonseca, I. Duque-Ingunza, B. De-Rivas, L. Flores- Giraldo, J.I. Gutie'rrez-Ortiz "Kinetics of catalytic glycolysis of PET wastes with sodium carbonate.", Chemical engineering journal, 168, 312-320, 2011.

Shukla, S.R.; Harad, A.M." Glycolysis of polyethylene terephthalate waste fibers" . Journal of applied polymer science ,97, 513-517, 2005.

T. R. Meng and M. A. Latta, "Physical properties of four acrylic denture base resins," Journal of The Journal of Contemporary Dental Practice, Volume 6, No. 4, November $15,2005$.

T. K. Mowade, S. P. Dange, M. B. ,akre, and V. D. Kamble, "Effect of fiber reinforcement on impact strength of heat polymerized polymethyl methacrylate denture base resin:in vitrostudy and S.E.M. analysis," Journal of Advanced Prosthodontics, vol. 4, no. 1, pp. 30 $36,2012$.

Uzun G., Hersek N., Tinçer T., "Effect of five woven fiber reinforcements on the impact and transverse strength of a denture base resin," Journal of Prosthetic Dentistry, vol. 81, no. 5, pp. 616-620, 1999.

Vojdani M., Khaled A. R., "Transverse strength of reinforced denture base resin with metal wire and E-glass fibers," Journal of Dentistry, vol. 3, pp. 167-172, 2006.

V. Sinha, M.R. Patel, J.V. Patel, J. Polym. Environ. Pet Waste Management by Chemical Recycling: A Review. Journal of Polymers and the Environment. Vol.18, pp.8-25, 2010. 